\title{
The Implementation of SAK ETAP to The Financial Report of SMEs
}

\author{
Nur Fani Arisnawati \\ IAIN Pekalongan \\ fanirisna@gmail.com
}

\begin{abstract}
This study aims to determine the preparation of Financial Report based on SAK-ETAP and constraints on the preparation of Batik Ar-Radhah SMEs in Pekalongan City. This research method uses a qualitative approach. This study uses primary data on the SMEs Batik Ar Radhah Pekalongan City. Data collection techniques using triangulation techniques, namely participant observation, interviews, and documentation. The sample in this study was selected based on a purposive sampling collection technique. Data analytic technique with data reduction, data display, and conclusions. The results of the study are the financial statement components in SMEs Batik Ar-Radhah Pekalongan City are slightly different when compared to the financial statement format with SAK ETAP chassis. The financial format according to Batik Ar-Radhah Pekalongan CitySMEs is current assets, trade receivables and other receivables, trade payables, short-term liabilities, and equity. In SAK ETAP regulates the existence of current assets: cash and cash equivalents, inventories; non-current assets, short-term liabilities, and long-term liabilities and equity. Constraints faced due to the lack of human resources in the field of financial accounting and financial report socialization based on SAK-ETAP by the Pekalongan City Government through training. So the suggestion from the author, it is better if human resources must be supported by its quality. For example: providing scholarships for employees of S1 Accounting / S1 Management education; employees are involved in training activities from Disperindagkop and other institutions.
\end{abstract}

Keywords: SMEs Batik Ar Radhah, Financial Statement and World City of Batik

\section{A. INTRODUCTION}

The label of a City of Batik for Pekalongan is proved by the Brand image of "The World City of Batik". It has been a common thought that Indonesian batik is officially recognized by Unesco by being included in the Representative List of the Intangible Cultural Heritage of Humanity. The inclusion of Indonesian Batik in the UNESCO Representative List of Intangible Cultural Heritage of Humanity is a form of an international acknowledgment of one of Indonesian culture, which is expected to motivate and lift the dignity of batik artisans, support the business and improve people's welfare. Regarding the growth of Batik SMES in Pekalongan City, there were 19,615 SMEs in total with the income is Rp1.84 billion and the asset is Rp1.88 billion until November 2015. 
The world recognition for batik provides a positive influence on the wide spreading batik market in various countries. The growth of batik business unit for five years from 2011 to 2015 were $14.7 \%$, from 41,623 units to 47,755 units in total. (Indonesian Ministry of Industrial Affair, 2016).

SMEs Batik Ar-Radhah is a trading business which sells wholesale or retail batik products. It is located in the batik shopping area of Al-Fairuz Mosque, Pekalongan City, which is on the Pantura (the north route) close to Pekalongan Bus Station. This shop sells various types of batik and its income reaches Rp. 350,000,000 per year. This turnover is in accordance with the of Law No. 20 of 2008. SMEs Batik AR-Radhah Pekalongan has already have monthly financial report.

Micro, Small and Medium Enterprises (SMEs) play an important role in economic growth and employment in Indonesia. The function of the enterprises are as an effort to unite, direct and develop the creative, creative and business power of the people, especially those who are limited in their economic capacity so that they can participate in economic activities.

Jati et al. (2004) stated that at the present time, most SMEs still have not implemented appropriate accounting and reporting. The fact reveals that SMEs face various obstacles or problems caused by several factors, namely: low education, lack of understanding of informational technology, and lack of competence of financial reporting. Education is a learning process to increase knowledge gained through formal and non-formal education. Small-scale business actors should understand the use of informational technology, to ensure that what has been planned and programmed can be implemented. There are several qualitative characteristics that must be fulfilled in preparing the Financial Report(Sariningtyas, 2012).

The presence of Entity Financial Accounting Standards Without Public Accountability or better known as (SAK ETAP) is expected to provide convenience for SMEs in presenting financial report. SAK ETAP is also expected to be a solution to the company's internal problems, especially for management who only see the results of profits without seeing the actual financial condition

The existence of the Standar Akuntansi Keuangan Entitas Tanpa Akuntabilitas Publik (SAK ETAP)/ Indonesian Accounting Standards for Non-Publicly Accountable Entities is expected to provide convenience for SMEs in presenting financial statements. Besides, 
SAK ETAP is also expected to be a solution to the company's internal problems, especially for those who only regard the profits without considering the actual financial conditions.

The purpose of SAK ETAP is providing convenience for small and medium scale entities. IFRS-based Standar Akuntansi Keuangan (SAK) /Indonesian Accounting Standards (General SAK) is intended to the entities who have significant public responsibility and who carry out international activities. The general SAK is complicated to understand and it is applied to most small and medium scale business entities in Indonesia. In some cases, SAK ETAP provides more convenience for an entity than the General SAK which has more complex reporting regulations (Haryadi, 2010).

The Indonesian Accountants Association has prepared SAK (Indonesian Accounting Standards) for SMEs called by SAK-ETAP (Standar Akuntansi Keuangan Entitas Tanpa Akuntabilitas Publik/Indonesian Accounting Standards for Non-Publicly Accountable Entities) which has been officially effective since January 1, 2011. The entities Financial Reportbased on the Indonesian Accounting Standards includes; balance sheet, income statement, statement of changes in equity, cash flow statement, and notes of the financial statements. Prasetya (2012) mentioned small companies, includes SMEs, do not need to create Financial Report based on SAK rules. SAK ETAP provides more facilities for companies than SAK, which has more complex reporting requirements. In accordance with the SAK-ETAP scope, this standard is intended to the entities without public accountability (the entities which do not have significant public accountability, and do not publish general-purpose financial report).

Rudiantoro and Siregar (2011) conducted similar study explaining SAK ETAP is a hope to improve the quality of financial report. The biggest obstacle of it is the SMES entrepreneurs' low understanding of SAK ETAP.

This study aims to investigate whether the business type of SMEs Batik AR-Radhah have used SAK ETAP in the processing the Financial Report and find out the obstacles faced in implementing SAK ETAP-based Financial Report in the SMES Batik Ar-Radhah Pekalongan. 


\section{B. RESEARCH METHODS}

This study is a kind of descriptive research and it uses qualitative approach. The primary data of this study are SMEs Batik Ar-Radhah Pekalongan City, and the secondary data are the existing literature such as books, financial report documents, the internet and other literature relating to the discussion of this study. In collecting the data, this study uses observation, interviews and documentation. This study takes place in SMEs Batik Ar-Radhah Pekalongan City located on Jl. Dr. Sutomo, Baros, East Pekalongan, Pekalongan, Central Java 51121.

The sample of this study is selected based on purposive sampling technique. This study is not carried out in the entire population but focuses on the certain target by considering certain criteria that have been made for the object. The consideration is based on the purpose of the study. This research is conducted on several companies listed on the Indonesian Effect Exchange. The certain criteria made by the researcher is the income level of SMEs reaching Rp. 300,000,000 (Three Hundred Million Rupiah).

Object of this study is SMEs Batik Ar-Radhah Pekalongan City. According to the data obtained by the respondents regarding the SMEs criteria stated in Law Number 20 of 2008 which has income at least Rp. 350,000,000, -.

\section{RESEARCH RESULT AND DISCUSSION}

\section{Research result}

This is a qualitative research, which produces descriptive written and oral data. The researcher visited SMEs Batik Ar-Radhah Pekalongan City to conduct the interview and collect some data. The primary data is the result of the interview and the questionnaire, while the secondary data is SAK-ETAP manual and the example of SAK-ETAP-based financial report.

This research was conducted in SMEs Batik Ar-Radhah Pekalongan City, which is located on Dr. Soetomo street, Baros, East Pekalongan, Pekalongan City, Central Java 51121. It used purposive sampling in choosing the sample that it focused on the considered target. The SMES reached Rp. 300.000.000 as the income, and it is appropriate with the Constitution No 20 year 2008 requirment. In analyzing the data, there are several steps: data reduction of the financial statement; data display of the financial report analysis compared with SAKETAP; and verification of the data collected. 


\section{Discussion}

\section{The Implementation of SAK ETAP in SMES Batik AR-Radhah Pekalongan}

After observing and interviewing the financial statement presented by SMEs Batik ArRadhah in Pekalongan City, the researcher assumes that his format of the Financial Report adhered to the company's Financial Reportfrom large companies. Therefore, it is better for the SMES to use SAK ETAP compiled by the IAI (Ikatan Akuntan Indonesia / Indonesian Accountants Association) and acknowledged by the government.

\section{Balance}

The balance sheet components in SAK ETAP include: cash and cash equivalents, accounts receivables and other receivables, inventories, fixed assets, investment property, intangible assets, account debts and other debts, tax assets and liabilities, estimated liabilities and equity. The format of Financial Report based on SAK ETAP contains important information that helps various interested parties such as SMEs Batik AR-Radhah in Pekalongan City. The format is useful for applying credit in the bank. The components of the Financial Report in this balance is easily analyzed when it is applied in making financial statement by SMEs Batik Ar-Radhah Pekalongan City. In addition, if this SAK ETAP-based financial statement is appropriately implemented, it is helpful for the SMEs in making weekly, monthly, and annual financial report.

The balance form in SMEs Batik Ar-Radhah Pekalongan is slightly different with the SAK ETAP-based financial statement form. The SMEs balance sheet format contains current assets, accounts receivable and other receivables, trade debts and other debts, short-term liabilities and equity. On the other hand, SAK ETAP-based balance sheet format contains not only the form of Financial Report of the SMEs Batik Ar-Radhah Pekalongan City, but also regulates cash and cash equivalents, inventories, investment property, tax assets and liabilities, and estimated liabilities. Those elements distinct the components of SMEs Batik AR-Radhah SMEs financial report with SAK ETAP. Therefore, SMEs owners are possible to make SAK ETAP-based Financial Report to improve the Financial Report and they can be used to investigate the company's profits.

\section{Income statement}

The next discussed component is the income statement of SMEs Batik Ar-Radhah in Pekalongan City. 
The general income statement presented by the SMEs is in line with SAK ETAP, which can be proven by the contents of the income statement itself. SAK ETAP-based income statement contains income, financial part, profit or loss of investment, tax expense, and net profit or loss. This SAK ETAP- based income statement is very complete. The income even net profit and loss are calculated in detail, making it easier for the users of the Financial Report to analyze the total profit and loss gained by the company during the production process. Generally, SMEs income statement is almost similar with the SAK ETAP-based income statement. The SMEs Batik Ar-Radhah income statement contains income, cost of goods, pre-tax expense, and post-tax expense. The pre-tax expense and post-tax expense are used by the SMEs City to pay the tax amount.

\section{Important Posts in Financial Statements}

\section{Inventory}

Inventory is one of the important aspects in a business unit. Based on SAK ETAP principles, inventory involves sold assets in normal business activities which are materials or equipment used in the production or service delivery process. The inventory covers two very important components, namely measurement and disclosure. The first topic will be measurement.

According to SAK ETAP, the measurement of the inventory is determined based on the following principle: the one has the lower cost, between incomes and selling price, is reduced by the completing or selling cost. The inventory costs include all purchasing costs, conversion costs and the other costs. This is very complete measurement due to a lot of elements that must be measured. Certainly, this measurement improve the quality of a financial report.

In SMEs Batik AR-Radhah, the inventory is measured by calculating the difference between the selling price and the producing cost of. This practice was chosen because of limited understanding of the concept of inventory measurement. Financial report makers only understand the concept of inventory in simple way, affecting their way in measuring the inventory.

The inventory disclosures contain the total amount of inventories and their classification with an entity, the amount of expense-recognized inventories, the inventory reducing value, 
and the amount of stated appreciated inventories. When we read SAK ETAP disclosures carefully, it can be assumed the disclosure are very detailed. Therefore, SMEs Batik ArRadhah Pekalongan City do not apply this inventory disclosure concept.

The practice was done by the SMEs Batik Ar-Radhah Pekalongan City, which is the sample for this research. The SMEs discloses inventory by observing and calculating the inventory in the factory. This is a very simple and easy disclosure concept. Therefore, it is better for SMEs Batik Ar-Radhah Pekalongan City to use the concept of inventory disclosure as regulated by SAK ETAP because SAK ETAP has arranged all the ways to create a good financial statement that it can be used well by various interested parties.

\section{Fixed assets}

In recognizing the fixed assets in SAK ETAP, the cost of fixed assets will be recognized if a post can be assessed reliably and has the possibility of the economic benefits related to the post flows into the business entity's account. The recognition has been approved by the government enabling various interested parties to use in terms of making good financial report.

The differentce raise from the recognition of the fixed assets carried out by SMEs AR-Radhah Pekalongan City. SMEs recognizes a fixed asset when it is the first time for the SMEs in buying a fixed asset. For example, SMEs Batik Ar-Radhah Pekalongan City bought a new machine for sewing. The accounting cost of the machine is recognized when the SMEs buys the machine for the first time from a shop or seller. In the future, by the existing of SAK ETAP, SMEs Batik Ar-Radhah Pekalongan can implement the concept of recognizing fixed assets based on the SAK ETAP concept in processing the financial statement.

In SAK ETAP, depreciation is recognized in the income statement, unlike in the other posts which require the accounting cost of fixed assets. The process of calculating the depreciation is indicated in several ways, including decreasing balances, economic life, and straight lines. This depreciation calculation can facilitate the entity in calculating the amount of depreciation value and it will be reported in the income report.

Meanwhile, after interviewing SMEs Batik Ar-Radhah in Pekalongan City, it was revealed that the depreciation was stable every year. This calculation basically uses a straight line system so the amount of decreasing balance is stable every year. 
SAK ETAP-based disclosure do look detailed, which demotivates SMEs to implement SAK ETAP in their Financial Report due to the low quality of HR (Human Resources). As the result, the employees find difficulties in implementing the disclosure to report the financial report. This fact was stated by the employees of SMEs Batik Ar-Radhah Pekalongan City who made financial report. They stated that SMEs Batik Ar-Radhah Pekalongan do not apply the disclosure criteria because the criteria are considered too detailed and must be supported by HR (Human Resources) not coming from financial accounting.

\section{Income}

According to SAK ETAP, income is measured based on the fair value of payments received or still received, and income is included in the economic benefits which must still be grossly received. A different thing was found from the interviews with the SMEs Batik ArRadhah Pekalongan City. The SMEs measures the income based on consumer payments for purchasing the goods. Therefore, there is a difference in the concept of income measurement between SMES Batik Ar-Radhah Pekalongan City and SAK ETAP-based income measurment. According to the SMEs Batik Ar-Radhah Pekalongan, the income is measured based on payments from consumers for the purchasing products of the SMEs. On the other hand, SAK ETAP-based measurement is measured based on the fair value of payments received or still must be received. Therefore, by conducting this research, hopefully the SMEs will change the measurement technique.

\section{Constraints of the implementation of SAK-ETAP in SMES Batik Ar-Radhah Pekalongan}

Several constrains faced by SMES Batik Ar-Radhah Pekalongan City include the imperfection in applying the manual Financial Report into MS Excel. The other constraints are the low understanding of SMEs entrepreneurs on SAK ETAP. Jati et al. (2004) stated that recently most SMEs still do not hold accounting records and reporting properly. In fact, SMEs face various obstacles or problems as the result of several factors, namely: low education, lack of technology understanding, and lack of reliability in understanding the characteristics of financial report. I have quote from Aditya, O., \& Naomi, P. (2017), for example, such as the Enron and World Com companies, explaining that providing lessons for risk, even though 
Financial Report have been routinely issued does not mean that a company will be free from business risks. Risk management is a fundamental concern of SMEs that companies are open to the current global era. This is because in the global era, businesses are faced with an environment with very high uncertainty and complexity. Constraints faced due to the lack of human resources in the field of financial accounting and financial report socialization based on SAK-ETAP by the Pekalongan City Government through training. So the suggestion from the author, it is better if human resources must be supported by its quality. For example: providing scholarships for employees of S1 Accounting / S1 Management education; employees are involved in training activities from Disperindagkop and other institutions.

\section{CONCLUSION}

\section{Conclusion}

The Batik Ar-Radhah Pekalongan City SMEs Financial Report are current assets, trade receivables and other receivables, trade payables and other debt, short-term liabilities, and equity. SAK ETAP regulates the existence of cash and cash equivalents, inventory, investment properties, tax assets and liabilities, and estimated liabilities, which distinguish the different components of Batik AR-Radhah's Financial Report from the others. As a result of the presence of SAK ETAP, Batik AR-Radhah Pekalongan City SMEs are able to make better financial reports that can be utilized to observe profits. therefore Batik Ar-Radhah SMEs must improve their financial statements. By recruiting employees who are experts in the field of Islamic Accounting or providing scholarships to old employees to study in Islamic Accounting study programs

\section{Limitations}

The absence of human resources mastering financial accounting becomes the obstacle for SMES Batik Ar-Radhah Pekalongan City in applying financial recording in accordance with SAK-ETAP. The government and the related parties have not maximally disseminated and trained the implementation of SAK ETAP to the SMES Batik Ar-Radhah Pekalongan City.

\section{Suggestion}

Based on the results, conclusions and limitations of this research, the author suggests the 
next researchers to conduct researches on the application of SAK-ETAP for different types and location of SMEs. Besides, hopefully the researches will conduct surveys to the relevant parties taking parts in the successful implementation of SAK-ETAP, including the government, community organization, or others.

\section{REFERENCES}

Aditya, O., \& Naomi, P., Penerapan Manajemen Risiko Perusahaan dan Nilai Perusahaan di Sektor Konstruksi dan Properti, Esensi: Jurnal Bisnis dan Manajemen, 7(2), 167-180, 2017.

Augustine, Y., \& Kristaung, R., Metodologi Penelitian Bisnis dan Akuntansi. Jakarta: Dian, 2013.

Bahri, S., Pengantar Akuntansi Berdasarkan SAK ETAP dan IFRS, 2017.

Bustami, Bastian \& Nurlela, Akuntansi Biaya, Edisi Pertama, Mitra Wacana Media: Jakarta.

Cahyono, A. T., Meta Teori Standar Akuntansi Keuangan di Indonesia- Contaduriay Administracion, 235. 7 Edition, 2 ${ }^{\text {nd }}$ Book. Jakarta: Salemba Empat, 2011.

Emzir, Metode Penelitian Kualitatif :Analisis data, Jakarta: Rajawali Pers, 2014.

Entrepreneurial Small Firms. International Journal of Entrepreneurial Behaviour \& Research, 12 (6), 345-360.

Gunawan, Imam, Metode Penelitian Kualitatif: Teori dan Praktik. Jakarta: PT. Bumi Aksara, 2015.

Harahap, S. S., \& Yusuf, M., Akuntansi Perbankan Syariah, LPFE Usakti, 2010.

Huvat, Y. J., Analisis Penerapan Standar Akuntansi Keuangan Entitas tanpa Akuntabilitas Publik (Sak Etap) pada Koperasi Cu (Credit Union) Daya Lestari di Samarinda, Ekonomia: 6(1), 923, 2017.

Ikatan Akuntan Indonesia, Pedoman Standar Akuntansi Keuangan, 2007.

Ikatan Akuntan Indonesia, Standar Akuntansi Keuangan Entitas Tanpa Akuntabilitas Publik, Dewan Standar Akuntansi Keuangan: Jakarta, 2009.

Jati, H., B. Bala, \& O. Nisnoni, Menumbuhkan Kebiasaan Usaha Kecil, 2004.

Kementerian Perindustrian, Pekalongan World City of Batik, Retrieved on September 10, 2018.

Kieso, D. E., Weygandt, J. J., \& Warfield, T. D, Intermediate Accounting (13th ed.), New Jersey: John Wiley \& Sons (Asia) Pte Ltd, 2010.

Leries, Floren Violetfin; Arza, Fefri Indra; Ramayani, Citra, Penerapan Standar Akuntansi Keuangan Entitas TanpaAkuntabilitas Publik (Sak Etap) (Studi Kasus Pada CV. CitraPandion Bernas di Kabupaten Solok), Jurnal Akuntansi, 2014.

Maseko, N. \& O. Manyani, Accounting Practices of SMEs in Zimbabwe: An Investigative Study of Record Keeping for Performance Measurement (A Case Study of Bindura), Journal of Accounting and Taxation, Vol 3 (8), 171-181, 2011.

Mazanai, M. and O. Fatoki, Perceptions of Start-up Small and Medium-Sized Enterprises (SMEs) on the Importance of Business Development Services Providers (BDS) on Improving Access to Finance in South Africa, Journal of Social Science, Vol 30 (1), 31-41, 2012.

Muhammad, Metodologi Penelitian Ekonomi Islam, Jakarta: PT. Raja Grafindo Persada, 2008. 
Narsa, N. P. D. R. H, SAK ETAP sebagai Sosulus Overload Standar Akuntansi Bagi Usaha Mikro Kecil dan Menengah, dan Koperasi, Ekuitas: Jurnal Ekonomi dan Keuangan, 1(1), 44-65, 2018.

Rahmawati, T., \& Puspasari, O. R., Implementasi SAK ETAP Dan Kualitas Laporan Keuangan SMES Terkait Akses Modal Perbankan, Jurnal Kajian Akuntansi, Vol 1(1), 2017.

Rakyat, Azaria, \& Vina Mukti, Penerapan Akuntansi pada SMES Unggulan di Kabupaten, 2013. Sariningtyas, dkk., Standar Akuntansi Keuangan Entitas Tanpa Akuntabilitas Publik Pada Usaha Kecil dan Menengah, Jurnal Akuntansi Keperilakuan Indonesia, Vol. 1 Hal. 90-101. ISSN 1475-1488, 2011.

Sugiyono, Metodologi Penelitian Bisnis, Bandung: Alfabeta, 2008.

Undang-Undang Republik Indonesia No. 20 Tahun 2008 tentang Usaha Mikro

Wehantouw, A. B., \& Tinangon, J. J., Analisis Laporan Arus Kas Operasi, Investasi dan Pendanaan pada PT. Gudang Garam Tbk., Jurnal EMBA: Jurnal Riset Ekonomi, Manajemen, Bisnis dan Akuntansi, Vol 3(1), 2015.

Weygandt, J. J., Kieso, D. E., \& Kimmel, P. D., Pengantar Akuntansi, Edisi Tujuh, Jilid 2, Penerjemah Desi Adhariani, Vera Diyanti. Jakarta Selatan: Penerbit Salemba Empat, 2011. 